\title{
Family composition of Muscoidea communities in adjacent areas of secondary tropical forest and pasture field in Rio de Janeiro, Brazil
}

\author{
Astrid Caldas ${ }^{1}$ \\ Josimar Ribeiro de Almeida ${ }^{2}$ \\ José Mário A'Almeida ${ }^{3}$
}

\begin{abstract}
The Muscoidea community of two adjacent areas was sampled. For eight months one area was of secondary tropical forest and the other was an open field used for cattle grazing. The main purpose of the study was to investigate if there would be any differences in abundance, family diversity, community composition and bait attractiveness. Results suggest that the change in the environment resulted in a reduction of overall abundance, but not a reduced diversity in terms of families. None of the families was led to a marked decrease or increase, as might be expected in a disturbed environment. The changes observed in the community composition were not significant for the distribution and abundance rank of the families within that community. The environmental change also seemed to affect the way the flies responded to the baits.

KEY WORDS. Muscoidea community, abundance, bait attractiveness, deforestation, diversity
\end{abstract}

Diversity studies have suggested that communities found in more complex systems tend to be more diverse, whereas those found in disturbed or less complex systems usually show a few dominant species in an overall less diverse community (PIANKA 1978; MAGURRAN 1988). According to this assumption, communities found in forests would be more diverse than same-taxon communities found in fields or other less complex areas.

Communities of Muscoidea can be used as comparative indicators of environmental changes, especially the ones due to human activity, because these flies have high levels of synanthropy (BAUMGARTNER \& GREENBERG 1985; POLVONÝ \& ZNOJIL 1989; D'AlmeIDA 1992). Several species may be completely dependent on human activity, and the ready availability of feeding and reproductive substrates leads to high population levels. In their natural habitat, however, these flies may still display preferences and strategies to enhance their fitness and reproductive success.

This work comments on the family composition of the Muscoidea communities found during preliminary sampling in one area of secondary forest and one adjacent area of artificially open pasture field near the city of Itaguaí, Rio de Janeiro,

1) Department of Entomology, University of Maryland. College Park, MD 20742-4454, USA.

2) Departamento de Ecologia, Universidade Federal do Rio de Janeiro. Caixa Postal 68020 , 21941-590 Rio de Janeiro, Rio de Janeiro, Brasil.

3) Laboratório de Entomologia Médica, Universidade Federal do Rio de Janeiro. Caixa Postal 68020, 21941-590 Rio de Janeiro, Rio de Janeiro, Brasil. 
Brazil. Several studies have been done focusing on the structure of fly communities in different environments affected by human activity in Brazil (CARVALHO et al. 1984; ALMEIDA et al. 1985; LOMONACO \& ALMEIDA 1995a; SouzA et al. 1990). In the present study, both areas are equally close to human settlements and farms, and are subject to the same climatic conditions. The only differing characteristic is the vegetation.

\section{MATERIALS AND METHODS}

The study areas were both privately owned and located within a short distance of one another, in the town of Seropédica (22 $45^{\prime} \mathrm{S}$ and $43^{\circ} 41^{\prime} \mathrm{W}$ ), in the state of Rio de Janeiro, Brazil. The forested area is called Experimental Forest Station (EFLEX), and the grazing field area is part of the Caxias Farm.

Flies were captured with traps consisting of a cardboard box with four openings of eight centimeters each at the base of each side. The top was open leading into a funnel of white cloth through which the attracted flies were directed to a plastic container (SouZA et al. 1990). For each area three traps were hung $1 \mathrm{~m}$ from the ground and two meters distant from each other, each trap containing a different bait: chicken, fish, and human feces. These baits were chosen because of their high power of attraction for the Muscoidea flies (LOMONACO \& ALMEIDA 1995b). Collections were simultaneous, and each trap was left in the field for seven days, once a month, for a total of eight months (January through August, 1996), after which sampling in the areas was not possible anymore due to the expiration of permits. The trapped flies were sorted by family, and kept for later species identification. These specimens are deposited in two institutions: Fundação Oswaldo Cruz (Rio de Janeiro) and Universidade Federal Rural do Rio de Janeiro.

\section{RESULTS}

A total of 5517 individuals were collected in the two areas. More individuals (3622) were captured in the forested area than in the open field area (1895). They belonged to seven families: Sarcophagidae, Fanniidae, Ulidiidae (Otitidae), Phoridae, Calliphoridae, Muscidae, and Sphaeroceridae. All were represented in both areas, but with different relative frequencies within the community. The composition of the community and the relative frequency of the families captured per bait in each area is summarized in tables I and II.

Secondary Forest. Capture per bait per family in this area can be seen in table I. Sarcophagidae was the highest represented family, having been collected in all months. The second family in abundance was Fanniidae, collected over seven months - no specimens from this family were captured in January. Third in abundance was Ulidiidae (Otitidae), collected in six out of the eight months - no specimens collected in January and August. Fourth in abundance was Phoridae, present in seven months - no individuals were collected in January (the only family collected in January was Sarcophagidae). The fifth most abundant family was Calliphoridae, collected from February through July. The sixth most abundant family was Muscidae, collected also from February through July, and mostly on fish. 
Table I. Structure of the Muscoidea community and relative attractiveness of baits at the Experimental Forest Station, Rio de Janeiro. (n) Total number captured, (*) indicates most effective bait.

\begin{tabular}{lrcccc}
\hline \multicolumn{1}{c}{ Families } & $\mathrm{n}$ & $\%$ & Human feces & Fish & Chicken \\
\hline Sarcophagidae & 1375 & 0.38 & 28.3 & $44.6^{*}$ & 27.1 \\
Fanniidae & 1076 & 0.30 & 7.0 & 42.1 & $50.9^{*}$ \\
Ulidiidae & 409 & 0.11 & 15.2 & 41.8 & $43.0^{*}$ \\
Phoridae & 312 & 0.09 & 1.3 & 4.5 & $94.2^{*}$ \\
Calliphoridae & 219 & 0.06 & 3.2 & $63.5^{*}$ & 33.4 \\
Muscidae & 198 & 0.05 & 27.0 & $44.0^{*}$ & 29.0 \\
Sphaeroceridae & 33 & 0.01 & $97.0^{*}$ & 3.0 & - \\
\hline
\end{tabular}

The least represented family in the forested area was Sphaeroceridae. Only 33 individuals were captured in four months: February, March, June, and July, most of them collected on human feces, and a few on fish in the month of July. No individuals were attracted to chicken.

Pasture field. Capture per bait per family in this area can be seen in table II. In this area, all families were present in January, as opposed to the forested area where only Sarcophagidae was present in this month. Fanniidae was not collected in February and August; Muscidae, Ulidiidae (Otitidae), and Phoridae were not collected in August; and Sphaeroceridae was only captured in January and June.

Five out of the seven sampled families showed different bait preferences in the forest and in the field: Faniidae, Sarcophagidae, Calliphoridae, Ulidiidae, and Phoridae. Sphaeroceridae and Muscidae displayed the same preference in both environments.

Table II. Structure of the Muscoidea community and relative attractiveness of baits at the Caxias Farm, Rio de Janeiro. (n) Total number captured, $\left({ }^{*}\right)$ indicates most effective bait. Numbers in parenthesis show the abundance ranking of that family in table $\mathrm{I}$.

\begin{tabular}{lccccc}
\hline \multicolumn{1}{c}{ Families } & $\mathrm{n}$ & $\%$ & Human feces & Fish & Chicken \\
\hline Fanniidae (2) & 854 & 0.45 & 0.8 & $51.0^{*}$ & 48.2 \\
Sarcophagidae (1) & 587 & 0.31 & $79.5^{*}$ & 11.0 & 9.5 \\
Calliphoridae (5) & 114 & 0.06 & 7.0 & 26.3 & $66.7^{*}$ \\
Ulidiidae (3) & 107 & 0.06 & 14.0 & $55.0 *$ & 31.0 \\
Muscidae (6) & 107 & 0.06 & 15.0 & $68.2^{*}$ & 16.8 \\
Sphaeroceridae (7) & 80 & 0.04 & $100.0^{*}$ & - & - \\
Phoridae (4) & 46 & 0.02 & 6.5 & 15.2 & $78.3^{*}$ \\
\hline
\end{tabular}

\section{DISCUSSION}

A comparison between the two areas shows that there were differences both in the total number of individuals captured and the relative frequencies of the families that constitute the communities. The number of individuals trapped in the forested area was practically twice that of individuals trapped in the field area. The populations in the forest seem to have a higher density, as sampled by the traps. 
Sarcophagidae was more abundant in the forest, followed by Fanniidae, while Fanniidae prevailed in the field, followed by Sarcophagidae, but from what can be inferred the evenness was not particularly altered. Although the contribution of each family for the composition of each community was different, the proportional structure (the numerical distribution) was not significantly altered. The most common family in the forest represented $38 \%$ of the sampled individuals, whereas in the field the most common family accounted for $45 \%$. Comparing the second most represented family, in the forest it accounts for $30 \%$ of the total, and in the field for $31 \%$. Looking at the other families, ranked third, fourth, etc. for each area (Tabs I, II) it can be seen that the order is not the same for both areas, but the proportions of each family within both communities were reasonably similar. Calliphoridae accounted for $6 \%$ of the sampled flies in both areas, but is placed fifth in abundance in the forest and third in the field. Muscidae accounted for 5\% in the forest and $6 \%$ in the field, but is placed in sixth and fifth places respectively; Ulidiidae (Otitidae), Phoridae and Sphaeroceridae showed very small changes. Sarcophagidae and Fanniidae were the ones that traded places as the most common family and the runner-up for each area. The distribution of these proportions were tested with a Kolmogorov-Smirnov two group test and the result showed that differences between the two were not significant (chi-square $=0.013, p>0.05$ ). The relative abundances were tested through a rank-correlation (Spearman) test, and a parametric correlation (Pearson) test. The Spearman test had a result of $\mathrm{r}=0.63$, barely not significant at the level of 0.05 and showing that the relative abundances of the families within the communities are not quite the same. But the Pearson correlation after $\log$ transformation resulted in $r=0.72$, significant at the level of 0.05 . These two results together indicate that although the differences in the abundance of families between forest and field are not very marked, the communities composition can not be considered the same.

The results of bait attractiveness show that even though the areas are adjacent, there is a clear difference in the response of these flies to the resources represented by the baits. These differences for each area are important because they may be a result of reproductive strategies evolved by some species in the different families to minimize competition and increase fitness in an environment altered by human presence, and may explain the changes in the community structure from one area to the other. Because the baits are used as oviposition substrates and subsequent larval feeding resource, the fact that in different areas families display different bait preference may indicate adaptive features.

Four out of the five families that showed different bait preferences in each area preferred either chicken or fish. For instance, Calliphoridae significantly favored fish in the forested area, as opposed to chicken in the field area, while in a previous study in the Amazon area (PARALUPPI \& CASTELLÓN 1994) these flies consistently preferred cow lungs over fish. Changes in preference between fish and chicken, although ecologically significant, are not very surprising, because both are protein. Under this same reasoning, the different bait preference displayed by Faniidae, Ulidiidae, and Phoridae in the two environments can also be seen as ecologically significant but not particularly important in terms of radical changes 
induced by human-altered environments. But Sarcophagidae flies, which have been shown to prefer mostly fish over other baits in non-altered environments (e.g. LOMÔNACO \& ALMEIDA 1995b), in the present study were more attracted to fish in the forest and to feces in the field. Feces are a resource completely different in terms of nutrients, but very abundant in the field because of the cattle grazing. This may show that a preference evolved in the sense of using feces - where competition is lower, leading to a higher offspring success - as the favored substrate.

On a different note, Muscidae maintained its preference for fish in both areas, but was relatively more attracted to feces in the forest than in the field; and Sphaeroceridae maintained its preference for human feces in both areas, but in the field it was attracted only by the feces, whereas in the forest a few were captured on fish.

These preliminary results suggest that (1) the change in the environment resulted in a reduction of overall abundance, but not a reduced diversity in terms of families. None of the families was led to a marked increase, dominating the community, as might be expected in disturbed environments; (2) the community composition remained proportionally the same, with the two most represented families trading places as number one between the two environments but this change not being significant for the distribution and abundance rank of the families within the community; and (3) the environmental change affected the way the flies responded to the baits. Further sampling and replicates are needed to assess the full significance of these results.

ACKNOWLEDGMENTS. The authors thank Claudio J.B. Carvalho, Margarete Valverde, and Robert K. Robbins for critically reading the manuscript, and several undergraduate students for help during data collection. This work was supported by Universidade Federal do Rio de Janeiro.

\section{REFERENCES}

Almeida, J.R.; C.J.B. DE Carvalho \& S.R. Malkowsky. 1985. Dípteros sinantrópicos de Curitiba e arredores (Paraná, Brasil). II. Fanniidae e Anthomyidae. An. Soc. Ent. Bras. 14: 277-288.

Baumgartner, D.L. \& B. GreenBerg. 1985. Distribution and medical ecology of the blow flies (Diptera: Calliphoridae) of Peru. Ann. Entomol. Soc. Amer. 78: 565-587.

Carvalho, C.J.B. DE; J.R. Almeida \& C.B. Jesus. 1984. Dípteros sinantrópicos de Curitiba e arredores (Paraná, Brasil). I. Muscidae. Revta bras. Ent. 28: 551-560.

D'AlmeidA, J.M. 1992. Calyptrate Diptera (Muscidae and Anthomyidae) of the State of Rio de Janeiro - I. Synanthropy. Mem. Inst. Oswaldo Cruz 87: 381-386.

Lomonaco, C. \& J.R. AlmeidA. 1995a. Estrutura comunitária de dípteros muscóideos da restinga de Jacarepaguá, Rio de Janeiro, Brasil. Revta bras. Ent. 39: 891-896. 
1995b. Sazonalidade e uso de recursos para alimentação e oviposição de dípteros muscóideos na Restinga de Jacarepaguá, Rio de Janeiro, Brasil. Revta bras. Ent. 39: 883-890.

MagurRan, A.E. 1988. Ecological diversity and its measurement. Princeton, Princeton University Press, 179p.

PARALUPPI, N.D. \& E.G. CASTELlÓN. 1994. Calliphoridae (Diptera) em Manaus: I. levantamento taxonômico e sazonalidade. Revta bras. Ent. 38: 661-668.

PIANKA, E.R. 1978. Evolutionary Ecology. New York, Harper \& Row, $3{ }^{\text {rd }}$ ed., $416 \mathrm{p}$.

PolvoNÝ, D. \& V. ZNOJIL. 1989. Synanthropic trends in Urban and extraurban taxocenoses of Sarcophaginae (Diptera) in three Central European cities. Mem. Inst. Oswaldo Cruz 84 (suppl. 4): 441-447.

SouzA, A.M.; F.P. TeixeirA; I.R. Ribeiro; L.M. PenA; M.D. Oliveira \& C. LOMONACO. 1990. Dípteros muscóideos associados a excrementos de criadouros em ambientes rurais, Uberlandia - MG. Revta Cent. Ciênc. Biom. Univ. Fed. Uberl. 6: 9-14.

Recebido em 06.III.1998; aceito em 27. VIII. 1999. 